\title{
Podobieństwa i różnice w zakresie słowotwórstwa między gwarową polszczyzną północno- i południowokresową
}

Słow a k lu c z e: Kresy; polskie gwary kresowe; słowotwórstwo; opis konfrontatywny

K e y w or d s: Polish Eastern Borderlands; Polish borderland dialects; derivation; the comparative description

Rosnąca liczba publikacji poświęconych językowi Kresów wschodnich sprawia, że coraz więcej wiemy o pochodzeniu, współczesnej sytuacji i kształcie polszczyzny na tych terenach (por. Bibliografia na końcu artykułu). Zagadnienia związane ze słowotwórstwem pojawiają się jako znaczące segmenty tych opracowań bądź jako uwagi na ich marginesie. Brak dotychczas zestawienia konfrontatywnego. Moim zdaniem na tym etapie badań nad polszczyzną kresową można już poczynić uściślenia dotyczące różnic i podobieństw w warstwie słowotwórczej pomiędzy gwarami północno- i południowokresowymi.

Niniejszy artykuł stanowi próbę uporządkowania dotychczasowych ustaleń dotyczących zjawisk słowotwórczych charakterystycznych dla gwarowej polszczyzny północno- i południowokresowej - wraz z krótką charakterystyką i egzemplifikacją. 
Podstawą artykułu jest: dla Kresów północnowschodnich - materiał zawarty w opracowaniach B. Dubickiej(-Dwilewicz) (Dubicka 1986, Dwilewicz 1997), H. Karaś (2001), Z. Kurzowej (1993), J. Riegera (2006), H. Turskiej (1983), natomiast dla Kresów południowowschodnich są to wyniki własnych badań, opartych przede wszystkim na materiałach zgromadzonych przez J. Riegera i zespół Pracowni Polszczyzny Kresowej Instytutu Języka Polskiego PAN podczas wyjazdów terenowych na Ukrainę prowadzonych od r. 1989 (szerzej w: Czarnecka 2009, 2014).

W zestawieniu nie brałam pod uwagę polszczyzny na Białorusi - mimo iż opublikowano szereg cennych prac na temat fonetyki, morfologii czy leksyki (por. m.in. Веренич 1990; Rieger 2014; Smułkowa 2009, 2011), brak jak dotąd opracowań dotyczących stricte słowotwórstwa.

Należy pamiętać o różnej genezie polszczyzny na Kresach północnych i na Kresach południowych. Na północy mamy do czynienia z językiem nabytym - od XVII w. wsie drobnoszlacheckie stopniowo ulegały polonizacji na skutek napływu na tereny Wielkiego Księstwa Litewskiego polskiej szlachty, głównie z Mazowsza. Nieco później, prawdopodobnie w połowie XIX w., proces polonizacji językowej objął wsie chłopskie, pierwotnie białorusko- bądź litewskojęzyczne (Kurzowa 1993: 37 i nast.). Obecność polszczyzny na Kresach południowych jest efektem masowego osadzania się na tych terenach ludności etnicznie polskiej z różnych rejonów Polski - zwłaszcza na przełomie XVI i XVII w. (kolonizacja starsza) i w XIX w. (kolonizacja młodsza), nie jest to zatem wynik polonizacji ludności autochtonicznej (Rieger 2002: 16 i nast.).

Przedmiotem niniejszego artykułu są zjawiska słowotwórcze obserwowane w północno- i południowokresowych gwarach wiejskich (chłopskich, ludowych), tj. w języku polskojęzycznych wsi chłopskich. Omawiane zjawiska zostały podzielone na trzy grupy: 1) zjawiska wspólne, tj. efekty identycznych procesów słowotwórczych, podporządkowane tym samym regułom i wynikające z tych samych tendencji; 2) zjawiska wspólne o różnej genezie; 3) zjawiska swoiste wyłącznie dla poszczególnych odmian gwarowej polszczyzny kresowej. 


\section{Zjawiska wspólne}

Oczywiste jest, że z racji położenia geograficznego (m.in. kontakt z językowym żywiołem wschodniosłowiańskim, peryferyjne położenie względem Polski etnicznej) obydwie odmiany polszczyzny kresowej łączy szereg podobieństw gramatycznych, a więc także i słowotwórczych. Warto pamiętać, że niektóre z cech, w tym wypadku słowotwórczych, charakterystyczne są także dla dialektów Polski rdzennej - ze względu na określony kształt polszczyzny dialektalnej w ogóle, zwłaszcza z uwagi na zachowanie się w gwarach konstrukcji archaicznych. Jak zauważył S. Gala, ,[gwary], ustalone w rezultacie procesów innowacyjnych, mogą zachowywać stan dawniejszy w stosunku do polszczyzny ogólnej czy innych gwar. Mogą zatem przechowywać pewien zasób leksyki dawnej, która funkcjonuje w gwarze, być może występuje w ograniczonym zakresie i poświadcza dawne, istotne dla danej gwary wykładniki derywacyjne i ich funkcje" (Gala 2000: 34). Z drugiej strony, trzeba mieć na względzie, że część przywołanych poniżej wyrazów, podzielnych słowotwórczo, nie powstała na gruncie gwar - zostały one w całości przejęte $\mathrm{z}$ języków bezpośrednio wpływających na te gwary (głównie wschodniosłowiańskich), por. np. komnatuszka, kurczatko, normalno.

W zakresie słowotwórstwa można zatem wyróżnić następujące cechy wspólne gwarowej polszczyzny północno- i południowokresowej:

1) Duże natężenie i zróżnicowanie zdrobnień i spieszczeń jest zjawiskiem bodaj najczęściej wymienianym i najbardziej kojarzonym z językiem Kresów - tak północnych, jak i południowych. H. Karaś kwalifikuje je jako regionalizm frekwencyjny (Karaś 2001: 205). Na całych Kresach wschodnich notowano zatem bardzo liczne derywaty z sufiksami znanymi polszczyźnie ogólnej (wśród nich także derywaty zgodne z ogólnopolskimi), jak -ka, -ek, -ko, także drugiego stopnia, -eczka, -eczek, -eczko, np. domeczek, pagóreczek, papiereczek, woreczek, cebuleczka, chateczka, jagodeczka, koseczka, drzeweczko, gniazdeczko, jabłeczko, wiadereczko, -uszka, -uszek, np. chatuszka, gwiazduszka, komnatuszka, chlewuszek, koluszek, kwiatuszek, -ulka, -ulek, np. dziadulek, księżulek, ojczulek, babulka, mamulka, oraz z charakterystycznym dla Kresów -eńk-, np. papeńko, chlapeńka, mameńka, szpileńka (według Urbańczyka sufiks typowy dla terenów na wschód od Wisły - Urbańczyk 1968). Trzeba jednak pamiętać, że na północy wyrazy z sufiksami 
zakończonymi na -a (-ka, -eczka, -ulka i in.) notuje się także w formacjach rodzaju męskiego typu dziadunia, chtopczunia, ale wynika to $\mathrm{z}$ akania (przejścia nieakcentowanego - $e$ oraz $-o \mathrm{w}-a$ ) - jest to więc zjawisko o charakterze fonetycznym, a nie morfologicznym.

2) Duże natężenie i zróżnicowanie formacji ekspresywnych pejoratywnych, często z sufiksami o proweniencji wschodniosłowiańskiej, jak augmentativa z sufiksami -un, np. krzykun, bladun, brechun 'kłamca', szczekun, śmierdun, -aka, np. chojraka, rozbijaka, rozdziawiaka, zadawaka, zadziraka, -ucha, np. brechucha, pleciucha, rozwalucha 'rudera', smolucha, splucha 'śpioch', świntucha, -uha, np. draniuha, pleciuha, zawaluha, złodziejuha, -iszcze, np. dworyszcze, dziewczyniszcze, krowiszcze (na północy także -iszcza dla rodzaju nijakiego, jak babiszcza, bladziszcza), ale też znanymi z języka ogólnopolskiego, jak -ina // -yna, np. bladzina, chudzina, gadzina, poduszczyna, żebraczyna, -isko // -ysko, np. batwanisko, byczysko, starocisko, tumanisko, werecisko i in.

Następnie kolejno można wymienić zjawiska reprezentowane mniej licznie, jak:

3) Nazwy żon z sufiksem -icha // -ycha, np. bondarycha 'żona bednarza, bondara', bratycha 'bratowa', piekarycha, kowalicha, kupczycha, szewczycha. Zjawisko to uznaje się za jeden z bardziej typowych wpływów wschodniosłowiańskich. W tej chwili w dialektach kresowych funkcjonują głównie formacje zleksykalizowane; model jest słabo produktywny - w niektórych dialektach w ten sposób tworzone są nazwy żon od nazwisk mężów, jak Babiczycha ( $\leftarrow$ Babicz), Stasiuczycha $(\leftarrow$ Stasiuk) (Dwilewicz 1997: 66).

4) Nazwy abstrakcyjne na -ość, np. chytrość, drogość, głupość, gorzkosśc, nieodpowiedność [!], stodkość. Sam model abstractów na -ość jest bardzo produktywny w języku ogólnopolskim (Jadacka 2001: 80), na Kresach mamy jednak do czynienia z przekraczaniem norm łączliwości wynikającym zapewne z przejrzystości modelu słowotwórczego w porównaniu $\mathrm{z}$ ustabilizowanymi formacjami na $-o t a,-y c z$ i in.

5) Przymiotniki z sufiksem -owaty, np. ciemnowaty, ciężkowaty, czarnowaty, dalekowaty, trudnowaty utworzone od podstaw przymiotnikowych, co w polszczyźnie ogólnej jest zjawiskiem rzadkim, natomiast model przymiotnik + sufiks -оватий (-уватий) jest bardzo 
produktywny w języku ukraińskim, por. np. білув атий, довг уватий, темнуватий, товстуватий (Winkler-Leszczyńska 1964: 45, 46), podobnie w języku białoruskim przymiotnik +-aвambl: жаўmaв ambl, пуставаты, рыжсаваты, халаднаваты (Winkler-Leszczyńska 1964: 47, 48).

6) Przymiotniki z sufiksem -anny, np. ceglanny, szklanny, glinianny, drucianny.

7) Intensiva przymiotnikowe z sufiksami -eńki i -utki, np. czerwionieńki, malusieńki, młodzieńki, skromnieńki, żółcieńki, jedniutki, malutki.

8) Mieszanie formantów przysłówkowych -o, -e, np. bogacie 'bogato', ciężkowacie, petnie 'pełno', bezpieczno 'bezpiecznie', normalno 'normalnie', straszno 'strasznie'. Jest to jedna z cech archaicznych zachowanych w polszczyźnie kresowej.

9) Wahania w prefiksacji czasowników - wynikające z:

a) zachowania archaizmów, np. odrosnqć 'podrosnąć, postyszeć 'usłyszeć', roztworzyć 'otworzyć', umarznać 'zmarznąć';

b) zachowania archaizmów dzięki wpływom wschodniosłowiańskim bądź litewskim, np. naczać 'zacząć', obezwać się 'odezwać się, zgotować 'ugotować' (por. ukr. potoczne нaylamu i ogólne обізватися, зварити, ros. начать, сварить, brus. зварыиъь, lit. išvirti 'ugotować');

c) interferencji (na północy białoruskich i litewskich, na południu ukraińskich i rosyjskich), np. nagniewać się 'pogniewać się' por. ukr. нагнів атися; okończyć 'ukończyć (szkołę)' - por. ros. окончить; podzwonić 'zadzwonić' - por. ros позвонить, ukr. подзвон ити; рожrócić się 'odwrócić się' - por. ros. поверн уться, ukr. поверн утися; роzпајотіс́ się 'zaznajomić się' - por. ros. познакомиться; przenieść 'znieść' - por. ros. перенести; obgolić się 'ogolić się' - por. lit. apsiskusti; obkraść 'okraść' - por. brus. обакрасиі; sporzadkować 'uporządkować' - por. lit. sutvarkyti.

d) innowacji gwarowych, np. dopodgladać, dopodgryzać, natlumaczyć 'wytłumaczyć', wybuntować 'zbuntować'.

Brak tu stałego modelu czy reguły - wydaje się, że istnieje po prostu rozchwianie w zakresie przyłączania prefiksów, stąd czasem nawet trudno do- 
ciec, czy kształt danego derywatu wynika z interferencji, innowacji, czy też jest to zachowany archaizm.

\section{Zjawiska wspólne o różnej genezie}

Na szczególną uwagę zasługuje zwłaszcza pierwsze z wymienionych poniżej zjawisk, jako że istnieje ryzyko utożsamiania pozornie identycznych modeli słowotwórczych, tymczasem najprawdopodobniej są one efektem kontaktów poszczególnych dialektów z różnymi językami.

1) Formacje $z$ sufiksem - $\boldsymbol{u k}$ notuje się zarówno na Kresach północnych, jak i południowych. Na północy formant jest rezultatem kontaktów językowych z językiem litewskim (lit. sufiks -ukas; kačiukas 'kotek', Jonukas 'Janek', berniukas 'chłopczyk'), choć w procesie zapożyczania nie można wykluczyć wpływu białoruskiego. Sufiks - $\boldsymbol{u k}$ pojawia się w deminutivach, hipocoristicach, nazwach istot młodych (bachuruk, baraniuk, dzieciuk, gęsiuk, grzybuk, liściuk, tatuk, Jaruk, Władziuk), także w formacjach ekspresywnych nacechowanych pejoratywnie, zwłaszcza na Wileńszczyźnie (dziaduk). Często wyrazy z - $\boldsymbol{u k}$ mają akcent na sufiksie (Dwilewicz 1997: 62 i nast.; Karaś 2002: 263). Na południu natomiast formant $\boldsymbol{- u} \boldsymbol{k}$ jest pochodzenia ukraińskiego, występuje w nazwach istot młodych (bliźniuk, sarniuk, Żydziuk, por. też ukr. близнюк, сарнюк) i w ekspresivach pejoratywnych (bettuk, marzluk, zdechluk), zakres jego występowania jest nieco węższy (nienotowany w deminutivach ani w hipocoristicach), akcent jest zgodny z ogólnopolskim bądź na sufiksie $-u k^{1}$.

W tym miejscu warto przytoczyć stanowisko reprezentowane przez P. Czuczkę (Чучка 1963), a następnie L. Bednarczuka (1992: 64). Badacze podają argumenty, zgodnie z którymi sufiks $\boldsymbol{- u} \boldsymbol{k}$, pojawiający się równolegle w różnych językach Wielkiego Księstwa Litewskiego już od XVw., historycznie należy uznawać za wspólne dziedzictwo turecko-tatarskie, rozpowszechnione na skutek procesów onomastycznych.

2) Wahania w użyciu przyrostków tematycznych to jedno $z$ niewielu zjawisk związanych ze słowotwórstwem czasowników (por. opisane powyżej rozchwianie w zakresie przyłączania prefiksów czasownikowych).

${ }^{1} \mathrm{O}$ antroponimicznej funkcji formantu $-u k \mathrm{w}$ gwarach wschodniej Polski pisały m.in. B. Lindert (1967: 69 i nast.) oraz L. Dacewicz (1999: passim). 
$\mathrm{Na}$ Kresach północnych częściej notuje się iterativa z wtórnym -iwa- // -ywa-, typu spotykiwać, zamarzywać lub wynajmywać, kupywać, interpretowane jako tu archaizm peryferyczny zachowany pod wpływem wschodniosłowiańskim (Karaś 2002: 210 i nast.), na Kresach południowych zaś mamy iterativa z wtórnym -owa- lub -uwa-, np. towarzyszować 'towarzyszyć, wyparzować 'wyparzać', gościuwać sie 'gościć się' będące wynikiem językowego sąsiedztwa ukraińskiego i rosyjskiego (por. ukr. товаришув ати, випарювати, гостювати, ros. выn аривать) oraz formacje typu dopytować, wykopować, pokazuwać, których postać jest prawdopodobnie efektem wyrównania do tematu czasu teraźniejszego czasowników (dopytuję, wykopuje, pokazu$j e)$, przy czym analogiczne formacje ukraińskie na -uwa- stanowią tu czynnik podtrzymujący ${ }^{2}$.

\section{Zjawiska typowe dla poszczególnych odmian polszczyzny kresowej}

Generalnie różnice słowotwórcze między gwarami północno- i południowokresowymi, tak jak różnice w innych warstwach językowych, wynikają z różnego sąsiedztwa językowego oraz innych źródeł polszczyzny na poszczególnych terenach (o czym szerzej por. np. Rieger 1996). Poniżej przedstawiam zjawiska najbardziej charakterystyczne.

\section{Kresy północne ${ }^{3}$}

1) Szczególnie licznie w gwarach północnokresowych zachowały się typowe dla polszczyzny historycznej zaimkowe formacje archaiczne z sufiksem -en, np. każden, któren, całen (Dwilewicz 1997: 72).

2) Typowe dla tego regionu są również przymiotniki z sufiksem -eńki (także jako -ińki), np. kochanieńki, caleńki, bystreńki, drobnińki, wesolińki, malusińki (Dubicka 1986: 77).

${ }^{2}$ Można tu również upatrywać oddziaływania dialektalnych małopolskich form na -ować.

$3 \mathrm{~W}$ artykule nie zajmuję się różnicami między polszczyzną wileńską i kowieńską, choć niewątpliwie można by takie wyodrębnić. 
3) Z uwagi na mazowieckie pochodzenie napływowej ludności na Kresach północno-wschodnich i przyjęcie jej języka za wzór dla polonizujących się obszarów w gwarowej polszczyźnie północnokresowej mamy także nazwy istot młodych z sufiksem -ak, typu gęsiak, koźlak, psiak przy niemal całkowitym braku tego typu rzeczowników na -e.

Zanotowano również szereg zjawisk wynikających z wpływu litewskiego:

4) Deminutiva oraz hipocoristica z sufiksem -ytie (< -utie), np. krówutie 'krówka' (por. lit. karvute 'krówka'), chlebutie 'chlebek' (por. lit. duonute 'chlebek'), chatitie 'chatka', dziewczynitie 'dziewczynka' i in. (Karaś 2002: 264) oraz - notowane rzadziej - -utka, np. mamutka.

5) Augmentativa (najczęściej patronimika) z sufiksem -uć $(<-\bar{u} t i s)$, np. Pawlukuć, Rawduć, chamuć, smarkuć (Kurzowa 1993: 252).

6) Formacje pejoratywne z sufiksem -ajło, np. brzdakajło, brechajło, strachajto (także -ajta, np. bazgrajła, badziajła), również z podwojonym $t$. Sufiks -ajto jest najprawdopodobniej pochodzenia litewskiego, choć może to być również wpływ białoruski. Według W. Mańczaka pierwotnie został wyabstrahowany z litewskich nazwisk na -gaila, typu Bargaila, Dargaila, Dziugaila do polskich nazwisk na -ajto, -ajta, a dopiero w dalszej kolejności zaczął się pojawiać w rzeczownikach o nacechowaniu pejoratywnym (Mańczak 1975: 189-192).

7) Czasownikowe formacje na -ować typu grzybować 'zbierać grzyby', rybować 'łowić ryby', jagodować, gospodyniować (por. lit. žuva$t i$ 'łowić ryby', uoglati 'zbierać jagody i in.). To wyraźny wpływ bardzo produktywnego litewskiego typu czasowników (por. m.in. Karaś 2002: 317).

Sąsiedztwu białoruskiemu można przypisać obecność w dialekcie północnokresowym:

8) Abstractów na -ynia i -yń, np. głębinia, wyżynia, szerzynia, głębin, szerzyń, dtużyń (por. np. brus. гльбіня, вышшыня, шырыня itd.; Karaś 2002: 266).

9) Zaimków nieokreślonych z sufiksem (partykułą) -si, -ści (i z jego rozszerzoną postacią -ścik), np. jakiścik, ktościk, gdzieści, cościk, któryścik (por. brus. якісиі, десці, хтосиі itd.) (Kurzowa 1993: 254).

10) Przymiotników z sufiksem -iny (-yny), np. kaczyny 'kaczy', kociny 'koci', koziny 'kozi', gęsiny 'gęsi', por. brus. качыны, каціны, казліны, гусіны (Dubicka 1986: 77; Kurzowa 1993: 254-255). 


\section{Kresy południowe}

1) $\mathrm{Na}$ Kresach południowych dużą frekwencję mają nazwy istot młodych z na -e, -qtko, np. gesię, indyczę, lisię, psię, kociatko, koziatko, żabiatko przy niewielkiej liczbie rejestrowanych derywatów z -ak, -aczek oraz -a, -atko (o czym także niżej).

2) W polszczyźnie południowokresowej zanotowałam relatywnie dużo formacji dwurodzajowych z sufiksami zakończonymi na -a, typu -ula, -ara, -aka, -ucha wśród nazw ekspresywnych pejoratywnych, np. $z a-$ dziraka 'ten, kto z każdym zadziera; zabijaka', splucha 'śpioch', zadawaka 'człowiek, który się unosi, przemądrzały (zadaje się z każdym)' (48 formacji na prześledzonych 310 ekspresywów pejoratywnych, co stanowiło 15\%). Zjawisko dodatkowego wzmacniania pejoratywnej wartości znaczeniowej derywatów przez żeńską formę sufiksu jest charakterystyczne w pewnym stopniu również dla gwar Polski etnicznej (por. m.in. Kowalska 2001: 294), podobne w swojej strukturze, jednak znacznie mniej liczne formacje, notowano także na Kresach północno-wschodnich.

3) Typowa dla Kresów południowych jest stosunkowo wysoka produktywność formantu paradygmatycznego na $\boldsymbol{- a} \mathrm{w}$ dwurodzajowych nazwach ekspresywnych pejoratywnych, jak chlapa 'ten, kto chlapie językiem; plotkarz', podliza, bałamuta, niwuka 'nieuk', zadzira 'ten, kto zadziera z innymi; łobuz, prowokator'.

4) Licznie występujące nazwy mieszkańców z formantem -an, typu maćkowian, szarawczan, horodian, parafian moga być śladem dziedzictwa językowego bądź wynikać z wpływu języków wschodniosłowiańskich.

Wiele typowych zjawisk słowotwórczych jest rezultatem kontaktów polszczyzny południowokresowej z językiem ukraińskim (bądź gwarami ukraińskimi) oraz rosyjskim.

5) Za typowe dla dialektu południowokresowego można uznać deminutiva i hipocoristica rodzaju męskiego z formantami -ko i -o, np. wujko, stryjko, dziadko, piesio, dziado, co sygnalizowano także w opracowaniach dotyczących przedwojennej polszczyzny na tych terenach (por. m.in. Kurzowa 1983). 
6) Nazwy istot młodych na -a, -atko, np. kaczatko, koźlatko, kurczatko (por. ukr. кач атко, коз ятко, курчlатко). Sufiksy -a, -atko w języku ukraińskim regularnie rozbudowują wspomnianą kategorię nazw istot młodych (Аркушин 2004: 39, 66; Warchoł 1984: 131-132).

7) Deminutiva i hipocoristica z sufiksem -czyk, jak: chlebczyk, chliw$c z y k, c z u b c z y k$ (por. ukr. хлlббчик, хлівччик, чуубчик, także ros. чуубчик) oraz nazwy wykonawców czynności z sufiksami -czyk i -szczyk, np. skupczyk, fotografszczyk, barabanszczyk (por. ukr. барабанщик, ros. pot. фотографщик).

8) Przymiotniki z sufiksem -aczy, np. gęsiaczy 'gęsi', kaczaczy 'kaczy', kurzaczy 'kurzy' (por. ukr. гусяяий, качачий, курачий).

\section{Podsumowanie i wnioski}

Jak się wydaje, najliczniejsze są te spośród zjawisk różnicujących poszczególne odmiany gwarowej polszczyzny kresowej, które stanowią rezultat innego sąsiedztwa językowego. Ponadto zaznaczają się pewne cechy wynikające z różnego pochodzenia polszczyzny na Kresach północnych i południowych, występujące również w gwarach Polski etnicznej (jak choćby mazowieckie - $a k$ i małopolskie $-e$ w nazwach istot młodych). Rejestrowano także formacje dawne, podtrzymane wpływami obcymi bądź zachowane w wyniku izolacji od współczesnej polszczyzny ogólnej. Z powyższego zestawienia wynika, że można wyróżnić podobną liczbę zjawisk słowotwórczych wspólnych dla obydwu odmiany polszczyzny kresowej (w odmianie gwarowej), jak i zjawisk swoistych. Zjawisk wspólnych, łącznie z tymi o różnej genezie, zebrałam 11. Zjawisk swoistych - odpowiednio 10 dla gwarowej polszczyzny północnokresowej i 8 -dla południowokresowej. Należy zatem zachować ostrożność przy formułowaniu uogólniających wniosków dotyczących zjawisk słowotwórczych typowych dla gwar kresowych. 


\section{Bibliografia}

Bednarczuk L., 1992, Stosunki etnolingwistyczne na obszarze Wielkiego Księstwa Litewskiego. Zarys problematyki, w: J. Bartmiński, M. Łesiów (red.), Dzieje Lubelszczyzny, t. VI, Między Wschodem i Zachodem, cz. 4, Lublin: Lubelskie Towarzystwo Naukowe.

Czarnecka K., 2006, Uwagi o słowotwórstwie czasowników odczasownikowych w gwarach polskich na Ukrainie, w: J. Rieger (red.), Jezzyk polski dawnych Kresów Wschodnich, t. 3, Warszawa: Semper, s. 129-142.

Czarnecka K., 2009, Stowotwórstwo gwar polskich na Ukrainie. Rzeczownik. Czasownik, maszynopis rozprawy doktorskiej napisanej pod kierunkiem prof. dra hab. J. Riegera, Warszawa.

CZARneCKa K., 2010a, Fonologia czy słowotwórstwo? O kilku zjawiskach w gwarach polskich na Ukrainie, w: J. Rieger (red.), Studia nad polszczyznq kresowa, t. XII, Warszawa: Semper, s. 79-88.

Czarnecka K., 2010b, Rzeczowniki motywowane w gwarach polskich wsi Nowosielica i Zielona na Ukrainie, w: J. Rieger (red.), Studia nad polszczyzna kresowa, t. XII, Warszawa: Semper, s. 89-135.

Czarnecka K., 2014, Stowotwórstwo gwar polskich na Ukrainie. Czasownik, Kraków: Libron.

DAcEwicz L., 1999, Nazwy osobowe z sufiksem -uk/-czuk w historycznej antroponimii Białostocczyzny, w: Bogusław Nowowiejski (red.), Polszczyzna pótnocno-wschodnia, cz. 2, Białystok: Uniwersytet w Białymstoku. Wydział Humanistyczny, s. 193-199.

Dubicka B., 1986, Niektóre odrębności słowotwórcze polszczyzny wileńskiej, w: J. Rieger, W. Werenicz (red.), Studia nad polszczyznq kresowa, t. 4, Wrocław-Warszawa-Kraków-Gdańsk-Lódź: Ossolineum, s. 71-79.

Dwilewicz B., 1997, Język mieszkańców wsi Bujwidze na Wileńszczyźnie, Warszawa: DiG.

Dzięgiel E., 2003, Polszczyzna na Ukrainie, Warszawa: Semper.

Dzięgiel E., 2012, Archaizmy a interferencje w kontaktach języków blisko spokrewnionych (przykład polsko-ukraiński), Z polskich studiów slawistycznych, seria XII, Językoznawstwo, Warszawa, s. 13-19.

Gala S., 2000, Słowotwórstwo gwarowe a słowotwórstwo polszczyzny ogólnej, Rozprawy Komisji Językowej ŁTN, t. XLV, Łódź, s. 29-36.

JADACKa H., 2001, System stowotwórczy polszczyzny (1945-2000), Warszawa: Wydawnictwo Naukowe PWN.

Karaś H., 2001 (red.), Język polski na Kowieńszczyźnie. Historia. Sytuacja socjolingwistyczna. Cechyjęzykowe. Teksty, Warszawa-Wilno: Uniwersytet Warszawski. 
Pracownia Językoznawstwa Stosowanego Instytutu Języka Polskiego. Wydział Polonistyki, Vilniaus Universitetas. Lenku filologijos katedra. Filologijos fakultetas.

Karaś H., 2002, Gwary polskie na Kowieńszczyźnie, Warszawa-Puńsk: Wydawnictwo Aušra.

Kowalska A., 2001, Studia nad dialektem mazowieckim, Warszawa: Wydawnictwo Wyższej Szkoły Pedagogicznej TWP.

Kurzowa Z., 1983, Polszczyzna Lwowa i Kresów poludniowo-wschodnich do 1939 r., Warszawa-Kraków: Państwowe Wydawnictwo Naukowe.

Kurzowa Z., 1993, Język polski Wileńszczyzny i Kresów pólnocno-wschodnich XVI$-X X$ w., Warszawa-Kraków: Wydawnictwo Naukowe PWN.

LinDERT B., 1967, Formanty stużace do tworzenia nazw mieszkańców w językach stowiańskich, Lublin: Wydawnictwo UMCS.

MańCZaK W., 1975, Litewskie pochodzenie sufiksu -ajło, Jezzyk Polski LX, z. 3, s. $189-192$.

RiegER J., 1996, Co wiemy o języku polskim na Kresach Wschodnich?, w: Język polski dawnych Kresów Wschodnich, t. I, Warszawa: Semper, s. 11-16.

Rieger J., 2002, Język polski na Ukrainie w XX w., w: J. Rieger, I. Cechosz-Felczyk, E. Dzięgiel, Język polski na Ukrainie w końcu XX w. Cz. 1. Stan i status. Cechy charakterystyczne. Polszczyzna w Lwowskiem, Tarnopolskiem i na Podolu. Teksty, Warszawa: Semper, s. 11-51.

Rieger J., 2006, Polszczyzna gwarowa na Litwie, w: J. Rieger, I. Masojć, K. Rutkowska, Stownictwo polszczyzny gwarowej na Litwie, Warszawa: DiG, s. 11-47.

RIEGER J., 2014, Stownictwo polszczyny gwarowej na Brasławszczyźnie, Warszawa: Uniwersytet Warszawski. Wydział „Artes Liberales”: Wydawnictwo Naukowe Sub Lupa.

SmuŁkowa E. (red.), 2009, Brasławszczyzna: pamięć i współczesność, t. 2, Stownictwo dwujęzycznych mieszkańców rejonu (słownik brasławski), Warszawa: Wydawnictwa Uniwersytetu Warszawskiego.

SmuŁkowa E. (red.), 2011, Brasławszczyzna: pamięć i wspótczesność, t. 1, Historia regionu, charakterystyka socjolingwistyczna, świadectwo mieszkańców, Warszawa: Wydawnictwa Uniwersytetu Warszawskiego.

Turska H., 1983, Język polski na Wileńszczyźnie, w: J. Rieger, W. Werenicz (red.), Studia nad polszczyzna kresowa, t. II, Wrocław-Warszawa-Kraków-Gdańsk-Łódź: Ossolineum, s. 15-23.

URBAŃcZYк S., 1968, Zdrobnienia typu mateńka, serdeńko, maleńki. (Drobiazg ze stosunków językowych polsko-ruskich), w: Szkice z dziejów języka polskiego, Warszawa: Państwowe Wydawnictwo Naukowe, s. 356-359.

WARcho€ S., 1984, Geneza i rozwój stowiańskich formacji ekspresywnych z sufiksalnym -k- i -c, Warszawa-Łódź: PWN. 
WinkLeR-LesZCZYŃSKa I., 1964, Sufiksy przymiotnikowe -ity, -isty, -aty, -asty w języku polskim na tle ogólnosłowiańskim, Wrocław-Warszawa-Kraków: Zakład Narodowy im. Ossolińskich - Wydawnictwo Polskiej Akademii Nauk.

Zielińska A., 2002, Polska mniejszość na Litwie Kowieńskiej. Studium socjolingwistyczne, Warszawa: Slawistyczny Ośrodek Wydawniczy.

Аркушин Г., 2004, Іменний словотвір західнополіського говору, Луцк: Вежа.

Веренич В. Л., 1990, Польско-белорусское языковое взаимодействие (на материале мазурского островного говора в Полесье), w: J. Rieger, W. Werenicz (red.), Studia nad polszczyznq kresowa, t. V, Wrocław-Warszawa-Kraków-Gdańsk-Łódź: Ossolineum, s. 7-141.

ЧучкА П. П., 1963, До похождения и значения украінських іменникових утворень з суффиксами -ук, w: Тези доповідей та повідомлень VII наукової конферениії. Серія філологічна, Ужгород, s. 70-71.

\section{Similarities and differences in derivation between Northern and Southern Polish Eastern Borderland dialects}

\section{( s u m m a r y)}

The article is an attempt to organize the existing data on the phenomena of derivation in Polish Eastern Borderland dialects - Northern and Southern - with a short description and exemplification. Among the phenomena that differentiate both varieties of Polish Eastern Borderland dialects, those that are the result of different language neighborhood are most numerous. Certain features are the result of the different source of the Polish language on the Polish Eastern Borderlands Northern and Southern (as - $a k$ from Mazovia and $-e$ from the Lesser Poland in the names of young signifieds). In the lexical material from Polish Eastern Borderlands, the old formations, supported by foreign language influences or preserved as a result of isolation from contemporary Polish language, were recorded. A similar number of derivation phenomena, which are common to both varieties of Polish Eastern Borderland dialects (10) and specific phenomena (10 for the dialect of the Northern Polish Eastern Borderland and 8 for the Southern) are indicated in the dialect. 
